\title{
Cowbird parasitism of Pale-headed Brush-finch Atlapetes pallidiceps: implications for conservation and management
}

\author{
STEFFEN OPPEL, H. MARTIN SCHAEFER, VERONIKA SCHMIDT and \\ BORIS SCHRÖDER
}

\section{Summary}

Pale-headed Brush-finch Atlapetes pallidiceps is a restricted-range species that is threatened with extinction due to habitat loss. The total population of $60-80$ individuals achieved a reproductive output of only 0.74 young per breeding pair in 2002. Brood parasitism by Shiny Cowbird Molothrus bonariensis was a major factor reducing breeding success, affecting $38.5 \%$ of broods. Parasitism rates reached $50 \%$ in an ungrazed reserve, but only $14 \%$ on an adjacent grazed plot. The resulting difference in breeding success was not, however, attributable to vegetation parameters used to describe microhabitat use. Cowbird parasitism rates therefore seem to be influenced largely by factors operating at the landscape level. These may include grazing scheme, topography, humidity and host availability. It is suggested that lower species diversity and bird abundance rendered the grazed site less attractive to cowbirds. Current parasitism rates are of great conservation concern due to the low population size of Pale-headed Brush-finch, and the initiation of controlling measures is pressing. Management options described from intensive cowbird control programmes in North America are reviewed and evaluated for their applicability here. To combine the possibility of further data collection with commencement of immediate conservation action, we consider two alternative approaches. Nest monitoring and cowbird egg removal would enable the study of the distribution of parasitism in relation to landscape and vegetation variables, whereas cowbird shooting and nest monitoring might provide a larger short-term benefit to reproductive output. Habitat management, resumption of some grazing in the reserve and cowbird removal should be considered for the intermediate future.

\section{Introduction}

The endemic and Critically Endangered Pale-headed Brush-finch Atlapetes pallidiceps has a restricted geographic range and is currently limited to a small side valley of the Río Jubones drainage in southern Ecuador (Collar et al. 1992, Agreda et al. 1999, BirdLife International 2000). The total population is estimated at 6o-80 individuals (Krabbe 2004). While habitat loss from human landscape modification appears to be the main factor responsible for the limited distribution of Pale-headed Brush-finch, the absence of birds from suitable habitat within its former range indicates that other factors may have contributed to its decline (Krabbe 2004). Shiny Cowbird Molothrus bonariensis, an obligate brood parasite, is present in large numbers in the Rio Jubones drainage, where it prefers warm 
and dry habitats (N. Krabbe and F. Sornoza pers. comm.). It has been observed to parasitise Pale-headed Brush-finch, and cowbird parasitism is considered to have detrimental effects on the localised population of this species. Declines in sensitive species of limited geographic distribution elsewhere have been linked to the detrimental impact of brood parasitism by cowbirds (Brittingham and Temple 1983, DeCapita 2000, Rothstein and Cook 2000).

Cowbirds are largely associated with open forests and non-forest habitats (Coker and Capen 1995, Burhans 1997, Johnsgard 1997, Strausberger 2001) and have therefore benefited to a great extent from anthropogenic landscape modification (Rothstein and Robinson 1994, Donovan et al. 2000, Petit and Petit 2000, Ward and Smith 2000). The range of many cowbird species has expanded following the conversion of forest into fragmented and open habitat (Brittingham and Temple 1983, Peterjohn et al. 2000, Rothstein and Robinson 2000, Smith and Rothstein 2000). Shiny Cowbird is the most widespread brood parasite of South America, and has expanded its range considerably in recent decades (Fulton 1990, Baltz 1995, Cruz et al. 1995, Payne 1997, Kluza 1998, Marin 2000). It is a generalist brood parasite that has been recorded to parasitize 246 different species (Fraga 2002).

Cowbirds adversely affect the breeding success of their hosts through predation (McLaren and Sealy 2000), egg punctures (Massoni and Reboreda 2002), ejection of eggs and nestlings (Dearborn 1996, Wood and Bollinger 1997, Granfors et al. 2001) and competition between nestlings (Dearborn 1998, Lichtenstein and Sealy 1998). Parasitism rates in localities with high cowbird density can reach more than 90\% (Payne 1997, Smith 1999), and severely reduce the reproductive output of host species. Songbird species newly exposed to cowbird parasitism often suffer high parasitism rates (Cruz et al. 1995), and the spread of cowbirds has often led to the decline or even local extinction of heavily parasitised host populations (Rothstein and Cook 2000).

Pale-headed Brush-finch was re-discovered in 1998, having been unrecorded for 30 years (Krabbe 2004). Its breeding success and the impact of cowbird parasitism have not previously been quantified. In March-July 2002 we surveyed the entire Pale-headed Brush-finch population and determined breeding success and factors affecting reproductive output. We focused our investigation on whether (1) Shiny Cowbirds parasitise a significant part of the population, and (2) whether habitat differences can account for varying breeding success between pairs. We used the results of this investigation to evaluate management schemes currently in place and propose new measures required to secure the population of Pale-headed Brush-finch.

\section{Study area}

The study area is located in the Yunguilla valley, approximately $50 \mathrm{~km}$ southwest of Cuenca in the upper Río Jubones drainage, province of Azuay, Ecuador $\left(3^{\circ} 13^{\prime} \mathrm{S} ; 79^{\circ} 16^{\prime} \mathrm{W}\right)$. It belongs to a moderately cool tropical area situated in a transitional zone between the arid lower Río Jubones valley and the humid upper reaches of the Andean west slope (Dercon et al. 1998). Mean annual precipitation, mean temperature and growing season differ strongly on a local scale depending on elevation and rain shadow. The region is intensively farmed, with corn crops 
and cattle pastures being the most dominant forms of land use (Dercon et al. 1998).

The study site, where the species was rediscovered in 1998 (Agreda et al. 1999), encompasses two hills of $c$. 50 ha each, ranging from 1,650-2,100 $\mathrm{m}$ above sea-level. One hill has been declared a reserve and has been ungrazed in recent years, whereas a population discovered subsequently on the neighbouring hill inhabits an area that is still grazed by cattle (Carlos and Sornoza 2001). Both hills feature semi-open habitats with dense arid scrub consisting mostly of composite and verbenaceous species, interspersed with grassland of old or recent pastures. Small stands of Acacia sp. and lauraceous trees are found in more humid parts. Fragments of semi-humid forest persist on western and southern slopes. Monocultural stands of dwarf bamboo Chusquea sp. form large patches of habitat in shallow depressions, ravines, and on the western slopes.

\section{Methods}

\section{Breeding success survey}

Breeding surveys were carried out from daylight to early afternoon every day from late March to early July 2002. Nests were located by following birds back to the nest (Martin and Geupel 1993). The outcome of nests was monitored by regular visits. Intervals between visits to active nests ranged from 3 to 5 days. If nests were found to be empty, the nest contents and surroundings were checked for signs of predation. Subsequently, the specific territory was observed intensively, to determine whether chicks might have fledged. Nest failure was denoted if (1) nests were destroyed and eggshells were found, (2) empty nests were found within 8 days of the last egg-stage visit, or (3) both adults could be observed for 60 consecutive minutes without feeding fledglings or returning to a nest. The last indicated failure because incubating females usually returned to the nest after $20( \pm 5)$ minutes, and fledglings were fed at least every 25 ( \pm 10) minutes (Oppel et al. in press-a). The rate of parasitism was calculated from the number of nests that were found with cowbird eggs or chicks, and from pairs that were feeding dependent cowbird fledglings.

For analysis, we defined every pair that raised at least one brush-finch fledgling throughout the season as successful. All pairs that were not recorded to have fledged at least one brush-finch offspring were labelled unsuccessful.

\section{Habitat measurements}

For every independent sighting of a Pale-headed Brush-finch, we recorded the following variables in an estimated $5 \mathrm{~m}$ radius circle around the perch site: grazing scheme (grazed or ungrazed), aspect, slope $\left(1=0^{\circ}-20^{\circ}, 2=21^{\circ}-40^{\circ}\right.$, $\left.3=>40^{\circ}\right)$, habitat density $(1=$ open, $2=$ semi-open, $3=$ open scrub with visibility $>10 \mathrm{~m}, 4=$ dense scrub with visibility 5-10 $\mathrm{m}, 5=$ dense scrub with visibility $<5 \mathrm{~m}$ ), vegetation cover (in the following categories: vines, bush, tree, herbaceous ground vegetation and grass, each assessed as $1=0-20 \%, 2=21-40 \%$, $3=41-60 \%, 4=61-80 \%, 5=81-100 \%$ ), as well as bamboo cover (in \% of total 
bush cover), and maximum and average vegetation height (both in $\mathrm{cm}$ ). Independence of point records was assured by maintaining a 5-min time lag between consecutive observations of the same individual. Individuals were identified by location and subtle plumage differences between partners. Effective sample size was limited by the small population (Machlis et al. 1985). We sampled approximately $95 \%$ of the entire population, and no individual contributed more than $5 \%$ to the dataset.

\section{Statistical analysis}

We compared the breeding success between pairs in the grazed and ungrazed part using contingency table analysis and chi-square statistics to test whether differences were significant at $P<0.05$.

In a second step, we investigated whether successful and unsuccessful pairs of Pale-headed Brush-finch exhibited different microhabitat use patterns in the study area. All point observation data were classified as successful or unsuccessful, and non-parametric tests (Mann-Whitney $U$-test) were used to examine differences between successful and unsuccessful points. We then applied a multivariate logistic regression, with nesting success as the dependent variable.

For this approach, multicollinearity between variables was reduced by eliminating one of a pair of variables with a Spearman's correlation coefficient of $r_{\mathrm{s}}>0.7$ (Sokal and Rohlf 1995, Fielding and Bell 1997). Backward stepwise logistic regression was then applied to the different sets of uncorrelated and less correlated variables to determine which variables significantly contributed to models that differentiated between breeding success states (Hosmer and Lemeshow 2000). We used Akaike's Information Criterion (AIC) to select the most parsimonious model that offered the highest degree of accuracy with the least variables (Burnham and Anderson 1992, Buckland et al. 1997). These variables were retained for the final model.

The final model was internally validated using the bootstrap procedure (Verbyla and Litvaitis 1989, Reineking and Schröder in press). We calculated receiver operating characteristic (ROC) curves to assess the predictive ability of the final model (Beck and Shultz 1986, Fielding and Bell 1997, Schröder 2002). The area under the ROC curve (AUC) in this case represents the model's ability to discriminate between nesting success and failure. A random prediction yields an AUC of 0.5 , whereas AUC values $>0.7$ can be regarded as acceptable, and $>0.8$ as excellent (Hosmer and Lemeshow 2000).

\section{Results}

We surveyed 26 territories of Pale-headed Brush-finch. In seven territories no breeding attempt was recorded, and in three of these it could not be assessed whether a partner of the territory holder was present or not. A total of 18 nests were found, and another seven broods were recorded through the observation of adults leading dependent fledglings within their territories. Of the 25 recorded breeding attempts, 10 were successful and in total 17 fledglings were raised in the study area. This corresponded to a mean reproductive output of 0.74 young per confirmed pair, or 0.65 per territory. 
Table 1. Breeding success of Pale-headed Brush-finch during the 2002 season in Yunguilla valley, Ecuador: a comparison between the ungrazed reserve and a grazed area of approximately equal size. Note that predation and parasitism rates are minimum figures only.

\begin{tabular}{lcc}
\hline & Yunguilla reserve, ungrazed & Pasture, grazed \\
\hline No. of pairs & 14 & 9 \\
Observation effort (hrs) & 791 & 75 \\
Breeding attempts recorded & 18 & 7 \\
Pairs without recorded broods & 3 & 2 \\
No. of nests found & 16 & 2 \\
$\quad 7$ Predated nests & 7 & 0 \\
Parasitized nests & 4 & 1 \\
Successful broods & 9 & 6 \\
Parasitized broods & 5 & 1 \\
Brush-finch fledglings raised & 7 & 12 \\
Cowbird fledglings raised & 2 & 1 \\
Mixed broods & 0.36 & 0 \\
Reproductive output (young/pair) & $50.00 \%$ & 1.33 \\
Parasitism rate & $43.75 \%$ & $14.28 \%$ \\
Predation rate & 0 & 0 \\
\hline
\end{tabular}

ancluding two broods for which no nest was found (see text).

At least 10 broods were parasitized by Shiny Cowbird, leading to a total of eight cowbird fledglings being raised by Pale-headed Brush-finch. A maximum of two cowbird fledglings were raised per pair, but six of seven successful parasitism events yielded only one cowbird fledgling. Two nests were deserted after being parasitized, and seven nests were predated by unknown predators (Table 1). In four of these it could not be assessed whether they had been parasitized. The minimum overall parasitism rate of the entire population was therefore $38.5 \%$, predation rate of discovered nests was $33.3 \%$, and $16.7 \%$ of nests were abandoned or failed due to unknown causes.

The breeding success of the nine pairs in the grazed area was significantly higher than that of the 14 pairs in the ungrazed reserve $\left(\chi^{2}=9.04, d f=1\right.$, $P<0.001)$. The mean reproductive output of Pale-headed Brush-finches in the grazed part was 1.33 young per pair, as opposed to 0.36 young per pair in the reserve (Table 1 ). Parasitism by Shiny Cowbird was more prevalent in the reserve, with at least $50 \%$ of all breeding attempts being parasitized.

Univariate analysis of microhabitat use as described by point observations indicated that successful pairs used points with lower grass cover and higher bush cover (Table 2). Grazing scheme was the only highly significant variable in all alternative logistic regression models. The best model retained grazing scheme, aspect (sin transformed), bamboo, vines and maximum vegetation height as explanatory variables (AIC $=982.792, n=746$; Table 3 ). Model performance was poor, and it had limited ability in classifying breeding success (AUC $=0.676,95 \%$ confidence interval $0.636-0.718$, Nagelkerke $\left.R^{2}=0.132\right)$.

\section{Discussion}

Pale-headed Brush-finch was exposed to considerable cowbird parasitism within the reserve. Parasitism rates found in this study were minimum figures only, 
Table 2. Microhabitat use of Pale-headed Brush-finch pairs successfully raising offspring versus pairs that failed to raise offspring in the 2002 breeding season in Yunguilla valley, Ecuador. Samples are sightings of individuals (point observations); results are given as mean $\pm \mathrm{SD}, z$ and $P$ values from Mann-Whitney $U$-tests.

\begin{tabular}{lcccc}
\hline & Successful pairs $(n=284)$ & Unsuccessful pairs $(n=462)$ & $z$ & $P$ \\
\hline Bush cover $(\%)$ & $68.08 \pm 25.60$ & $64.56 \pm 25.43$ & -1.97 & 0.048 \\
Tree cover (\%) & $4.21 \pm 11.27$ & $4.68 \pm 11.15$ & -1.38 & 0.250 \\
Grass cover (\%) & $26.90 \pm 27.02$ & $32.52 \pm 26.82$ & -1.97 & 0.002 \\
Herb cover (\%) & $19.33 \pm 16.08$ & $18.60 \pm 16.56$ & -1.38 & 0.331 \\
Bamboo (\%) & $23.45 \pm 30.23$ & $21.56 \pm 31.35$ & -3.17 & 0.253 \\
Vines (1-5) & $2.18 \pm 1.076$ & $2.09 \pm 1.13$ & -0.97 & 0.157 \\
Density (1-5) & $3.08 \pm 0.99$ & $3.12 \pm 1.08$ & -1.14 & 0.466 \\
Maximum height $(\mathrm{cm})$ & $455.99 \pm 171.77$ & $464.89 \pm 177.28$ & -1.41 & 0.310 \\
Average height $(\mathrm{cm})$ & $277.78 \pm 96.25$ & $273.72 \pm 91.95$ & -0.73 & 0.995 \\
\hline
\end{tabular}

Table 3. Logistic regression model coefficients and standard error (SE) of habitat variables differentiating between successful and unsuccessful pairs of Pale-headed Brush-finch in Yunguilla valley, Ecuador, based on point observations $(n=746)$. AUC denotes the area under the ROC curve.

\begin{tabular}{lcrr}
\hline Variables & Coefficient & SE & $P$ value \\
\hline Grazing scheme & 1.359 & 0.197 & $<0.001$ \\
Bamboo (\%) & 0.008 & 0.003 & 0.008 \\
Vines (1-5) & 0.162 & 0.074 & 0.043 \\
Maximum height (cm) & -0.001 & 0.001 & 0.029 \\
Aspect (sin transformed) & 0.771 & 0.161 & $<0.001$ \\
AUC & & 0.676 & \\
Nagelkerke $R^{2}$ & & 0.132 & \\
\hline
\end{tabular}

since nests were not monitored on a daily basis and unsuccessful parasitism attempts might have gone unnoticed. Predation rates were probably much higher in the ungrazed reserve than in the grazed area, and only slightly lower than parasitism rates. The detection of nest predation requires more intensive monitoring than applied in this study. Due to the unequal observation effort between grazed and ungrazed sites, we consider the bias too large to derive valid assumptions about nest predation rates. They will, therefore, not be discussed here. The unbalanced observation effort might also have introduced some bias in the pair estimates, since unsuccessful pairs in the grazed plot might have evaded detection. We used a conservative definition of breeding success to overcome the unbalanced observation effort. Successful pairs were easier to find than unsuccessful ones, and the latter required more observation effort to confirm their lack of success. With observation effort in the ungrazed part being roughly 1o times that in the grazed part, no successful pair would have been missed.

We assume that parasitism by Shiny Cowbird is one of the main factors contributing to the differences in breeding success. It should, however, be recognized that cowbird parasitism might have caused only $50 \%$ of failures. Moreover, parasitism and predation rates may vary significantly between years, and due to our limited study period we cannot assess the long-term mean of both rates. 
Factors influencing breeding success

Cowbird parasitism of songbirds is affected by nest concealment and structural diversity of under-storey vegetation (Burhans 1997, Larison et al. 1998, Staab and Morrison 1999, Tewksbury et al. 1999, Uyehara and Whitfield 2000). Both the univariate comparisons and the multivariate logistic regression model indicated that successful and unsuccessful pairs of Pale-headed Brush-finch differed only marginally in their use of vegetation. One of the most important variables in the logistic regression was grazing scheme, which was selected in all alternative models. Probability of breeding success in the grazed part was approximately four times as high as probability of failure (Table 3 ). This suggests that land use had an overriding effect on nesting success that is not explained by microhabitat use of birds.

The positive relationship of vines and bamboo with the probability of breeding success (positive regression coefficients in Table 3) might be related to reduced predation rather than cowbird parasitism. Bamboo and vines are important substrates for nest placement of Pale-headed Brush-finch, and this has been hypothesized to prevent predation by small mammals (Oppel et al. in press-a).

Factors that operate at the landscape scale may govern the distribution of cowbirds if vegetation structure within territories is not different enough to explain elevated parasitism levels (Tewksbury et al. 1999, Young and Hutto 1999). Burhans (1997) suggested that cowbird habitat preferences or host choice at the landscape scale might contribute to differences in parasitism. Steep and narrow valleys (Tewksbury et al. 1999) as well as increased humidity (N. Krabbe pers. comm.) have been suggested to lower cowbird abundance. In Yunguilla valley, western slopes are generally steeper and more humid. Pairs using more west-facing slopes had lower breeding success according to the logistic regression model (Table 3). However, none of these nest failures could be attributed to cowbird parasitism. While the poor performance of the model requires caution when interpreting its results, the lower breeding success on west-facing slopes indicates that humidity might reduce not only cowbird abundance and parasitism rates, but also general habitat quality for Pale-headed Brush-finch.

It has been demonstrated that cowbirds choose their breeding areas with respect to a high diversity and abundance of potential hosts (Barber and Martin 1997, Evans and Gates 1997, Robinson et al. 1999, Tewksbury et al. 1999, Young and Hutto 1999). The generally lower diversity and abundance of bird species in grazed areas (Taylor 1986, Ammon and Stacey 1997, Dobkin et al. 1998, Goguen and Mathews 1998) might have attracted fewer cowbirds and led to lower parasitism rates and therefore higher breeding success of Pale-headed Brush-finch in the grazed area in Yunguilla valley. In turn the ungrazed reserve might have attracted larger numbers of cowbirds through a higher availability of potential hosts. The reserve is currently in a process of succession towards a structurally more diverse vegetation, which often leads to a more diverse avifauna (Dobkin et al. 1998), thus providing more hosts for cowbirds. Pale-headed Brush-finch might be a preferred host due to its nesting habits close to openings (Burhans 1997, Davis and Sealy 2000, Oppel et al. in press-a), and due to its ability to raise two fledglings.

All studies provided to support the hypotheses of Shiny Cowbird distribution relate to Brown-headed Cowbird Molothrus ater of North America. Even within 
the North American continent, cowbirds exhibit marked regional differences in host and habitat use (Hahn and Hatfield 1995), and it has to be considered that some conclusions may not be transferable to the situation with Shiny Cowbird present in the Yunguilla valley.

While the differences in cowbird parasitism between grazed and ungrazed sites are intriguing, it might be more practical from a conservation perspective to consider Pale-headed Brush-finch as one single population in the Yunguilla valley, especially since the sites are connected and population exchange is not restricted. The data presented in this paper suggest that cowbird parasitism is of great conservation concern. Smith (1999) suggested cowbird control to be justified when parasitism rates exceed $60 \%$ over 2 years. This may not be applicable for Pale-headed Brush-finch, since small and isolated populations are not self-sustaining at parasitism levels of greater than 20\% (Greene et al. 1999). It therefore seems prudent to initiate management measures reducing the impact of cowbird parasitism.

\section{Management options}

Several different approaches have been used to control parasitism rates, or to remove cowbirds. The results of these programmes are highly variable (Rothstein and Cook 2000). The removal of large cowbird numbers at winter roosts or feeding sites has only limited applicability as a management tool, as the high mobility of cowbirds dilutes the removal effect across the landscape and numbers in breeding areas remain unchanged (Rothstein et al. 1987, Rothstein and Robinson 1994).

Most removal programmes in North America rely on large cage-traps as effective means of cowbird control (Hall and Rothstein 1999, Whitfield et al. 1999, Griffith and Griffith 2000, Rothstein and Cook 2000). Selective shooting has also been applied to remove cowbirds, but has yielded mixed results. While Eckrich et al. (1999) acknowledge site-specific shooting as an effective complementary tool to support landscape-scale management, shooting alone did not significantly reduce cowbird parasitism rates at a site in California (Whitfield 2000). Another option to reduce the impact of cowbird parasitism on the reproductive success of hosts is to monitor nests closely and remove cowbird eggs and chicks. While it is intrusive and requires a considerable level of skill (Griffith and Griffith 2000), nest manipulation has been demonstrated to be efficient and cost-effective, especially in remote areas where trapping is impractical (Winter and McKelvey 1999, Kus 2002).

Cowbird control has to be maintained for an infinitely long time, as cowbird populations at a regional level are not affected by most removal programmes (Hall and Rothstein 1999, Whitfield et al. 1999, DeCapita 2000, Hayden et al. 2000, Rothstein and Cook 2000). Despite often leading to reduced parasitism rates, cowbird removal has only occasionally triggered an evident increase in the target host population (Griffith and Griffith 2000), and it has been suggested that habitat quality or quantity might be more limiting than cowbird parasitism rates alone (DeCapita 2000).

Cowbird control does not eliminate the actual causes for declining populations (Hall and Rothstein 1999, Hayden et al. 2000, Rothstein and Cook 2000, Whitfield 
2000), and alternatives such as habitat restoration should therefore be sought (DeCapita 2000, Griffith and Griffith 2000). The provision of suitable habitat that enables populations to overcome brood parasitism without constant human interference requires solid scientific baseline data (Hall and Rothstein 1999). For Pale-headed Brush-finch, the resumption of low-intensity grazing and selective logging is proposed as a measure to restore and preserve semi-open shrub habitats (Oppel et al. in press-b). However, due to the inherent variability of host parasite interactions, results from a single field-season might not provide a sufficient basis for management decisions. The implementation of controlling measures is, however, pressing, given the low population size of Pale-headed Brush-finch. We consider two alternative approaches in an attempt to trade off the possibility of taking immediate action with the need to study parasitism patterns.

An intensive monitoring programme for Pale-headed Brush-finch should be carried out in the next breeding season. While variables that might explain parasitism can be recorded at parasitized and unparasitized nests, the removal of cowbird eggs and nestlings could minimize the impact of brood parasitism. This approach would enable the collection of more data on the distribution and causes of cowbird parasitism in the Yunguilla valley, and would help to increase the reproductive output of Pale-headed Brush-finch. It would, however, not reduce the impact associated with adult cowbirds removing eggs or nestlings of Pale-headed Brush-finch. The close monitoring of nests might also lead to increased predation rates (Martin and Geupel 1993). Furthermore, eggs of Shiny Cowbird and Pale-headed Brush-finch are both highly variable and show considerable overlap in colour and marking, rendering their reliable identification very difficult (Oppel et al. in press-a).

An alternative approach would be to take immediate action to reduce cowbird abundance and, potentially, parasitism rates. This would include selective shooting of cowbirds and the removal of tall vegetation (e.g. Agave spp., Eucalyptus spp.) that might serve as cowbird perches (Clotfelter 1998, Hauber and Russo 200o). Changes to the system will, however, limit the chance of further data collection and thus foreclose a better understanding of factors that influence cowbird parasitism. In order to enable further studies, shooting effort would need to be held constant across areas with different landscape features. This might be complicated by restricted access rights to private property. While an immediate reduction of cowbirds is likely to have some benefits for Pale-headed Brush-finch, this needs to be assessed with nest monitoring or breeding success monitoring. The disadvantages of the first approach would therefore apply to the second approach as well.

\section{Acknowledgements}

This study was funded by the German Academic Foreign Exchange Service (DAAD grant number 332404010), by the Sweden Club 300 and by the Royal Society for the Protection of Birds. We are grateful to F. Sornoza (Fundacion Jocotoco) and R. S. Ridgely for assistance in the project and granting access to the study area. C. Wickert and J. Heathcote assisted us during nest searches. The work benefited from correspondence with N. Krabbe, F. Bairlein and P. C. Stoddard, who also helped to improve the manuscript with their comments. 


\section{References}

Agreda, A., Krabbe, N. and Rodriguez, O. (1999) Pale-headed Brushfinch Atlapetes pallidiceps is not extinct. Cotinga 11: 50-54.

Ammon, E. M. and Stacey, P. B. (1997) Avian nest success in relation to past grazing regimes in a montane riparian system. Condor 99: 7-13.

Baltz, M. E. (1995) First records of the Shiny Cowbird (Molothrus bonariensis) in the Bahama Archipelago. Auk 112: 1039-1040.

Barber, D. R. and Martin, T. E. (1997) Influence of alternate host densities in Brown-headed Cowbird parasitism rates in Black-capped Vireos. Condor 99: 595-604.

Beck, J. R. and Shultz, E. K. (1986) The use of receiver operating characteristic (ROC) curves in test performance evaluation. Arch. Pathol. Lab. Med. 110: 13-20.

BirdLife International (2000) Threatened birds of the world. Barcelona, Spain, and Cambridge, United Kingdom: Lynx Ediciones and BirdLife International.

Brittingham, M. C. and Temple, S. A. (1983) Have cowbirds caused forest songbirds to decline? BioScience 33: 31-35.

Buckland, S. T., Burnham, K. P. and Augustin, N. H. (1997) Model selection: an integral part of inference. Biometrics 53: 603-618.

Burhans, D. E. (1997) Habitat and microhabitat features associated with cowbird parasitism in two forest edge cowbird hosts. Condor 99: 866-872.

Burnham, K. P. and Anderson, D. R. (1992) Data-based selection of an appropriate biological model: the key to modern data analysis. Pp. 16-30 in D. R. McCullough and R. H. Barrett, eds. Wildlife 2001: populations, based on an international conference on population dynamics and management of vertebrates (exclusive of primates and fish) held at Oakland, California, USA, July 29-31 1991. London, New York: Elsevier Applied Science.

Carlos, B. and Sornoza, F. (2001) Report on new population of Atlapetes pallidiceps discovered. Unpublished report. Quito: Fundacion Jocotoco.

Clotfelter, E. D. (1998) What cues do Brown-headed Cowbirds use to locate Red-winged Blackbird host nests? Anim. Behav. 55: 1181-1189.

Coker, D. R. and Capen, D. E. (1995) Landscape-level habitat use by Brown-headed Cowbirds in Vermont. J. Wildl. Manage. 59: 631-637.

Collar, N. J., Gonzaga, L. P., Krabbe, N., Nieto, A. M., Naranjo, L. G., Parker, T. A. and Wege, D. C. (1992) Threatened birds of the Americas. Cambridge, U.K.: International Council for Bird Preservation.

Cruz, A., Manolis, T. H. and Andrews, R. W. (1995) History of Shiny Cowbird Molothrus bonariensis brood parasitism in Trinidad and Tobago. Ibis 137: 317-321.

Davis, S. K. and Sealy, S. G. (2000) Cowbird parasitism and nest predation in fragmented grasslands of southwestern Manitoba. Pp. 220-228 in J. N. M. Smith, T. L. Cook, S. I. Rothstein, S. K. Robinson and S. G. Sealy, eds. Ecology and management of cowbirds and their hosts. Austin: University of Texas Press.

Dearborn, D. C. (1996) Video documentation of a Brown-headed Cowbird nestling ejecting an Indigo Bunting nestling from the nest. Condor 98: 645-649.

Dearborn, D. C. (1998) Begging behavior and food acquisition by Brown-headed Cowbird nestlings. Behav. Ecol. Sociobiol. 43: 259-270.

DeCapita, M. E. (2000) Brown-headed Cowbird control on Kirtland's Warbler nesting areas in Michigan. Pp. 333-341 in J. N. M. Smith, T. L. Cook, S. I. Rothstein, S. K. Robinson and S. G. Sealy, eds. Ecology and management of cowbirds and their hosts. Austin: University of Texas Press.

Dercon, G., Bossuyt, B., Bièvre, B. D., Cisneros, F. and Deckers, J. (1998) Zonificacion agroecologica del Austro Ecuatoriano. Cuenca, Ecuador: Promas, Universidad de Cuenca.

Dobkin, D. S., Rich, A. C. and Pyle, W. H. (1998) Habitat and avifaunal recovery from livestock grazing in a riparian meadow system of the Northwestern Great Basin. Conserv. Biol. 12: 209-221. 
Donovan, T. M., Thompson III, F. R. and Faaborg, J. R. (2000) Cowbird distribution at different scales of fragmentation: trade-offs between breeding and feeding opportunities. Pp. 255-264 in J. N. M. Smith, T. L. Cook, S. I. Rothstein, S. K. Robinson and S. G. Sealy, eds. Ecology and management of cowbirds and their hosts. Austin: University of Texas Press.

Eckrich, G. H., Koloszar, T. E. and Goering, M. D. (1999) Effective landscape management of Brown-headed Cowbirds at Fort Hood, Texas. Stud. Avian Biol. 18: 267-274.

Evans, D. R. and Gates, J. E. (1997) Cowbird selection of breeding areas: the role of habitat and bird species abundance. Wilson Bull. 109: 470-480.

Fielding, A. H. and Bell, J. F. (1997) A review of methods for the assessment of prediction errors in conservation presence/absence models. Environ. Conserv. 24: 38-49.

Fraga, R. M. (2002) Notes on new or rarely reported Shiny Cowbird hosts from Argentina. J. Field Ornithol. 73: 213-219.

Fulton, J. T. (1990) The Shiny Cowbird (Molothrus bonariensis) reaches Alabama. Alabama Birdlife 37: 1-3.

Goguen, C. B. and Mathews, N. E. (1998) Songbird community composition and nesting success in grazed and ungrazed pinyon-juniper woodlands. J. Wildl. Manage. 62: $474-484$.

Granfors, D. A., Pietz, P. J. and Joyal, L. A. (2001) Frequency of egg and nestling destruction by female Brown-headed Cowbirds at grassland nests. Auk 118: 765-769.

Greene, E., Jolivette, J. and Redmond, R. (1999) Lazuli Buntings and Brown-headed Cowbirds in Montana: a state-wide landscape analysis of potential sources and sinks. Stud. Avian Biol. 18: 135-143.

Griffith, J. T. and Griffith, J. C. (2000) Cowbird control and the endangered Least Bell's Vireo: a management success story. Pp. $342-357$ in J. N. M. Smith, T. L. Cook, S. I. Rothstein, S. K. Robinson and S. G. Sealy, eds. Ecology and management of cowbirds and their hosts. Austin: University of Texas Press.

Hahn, D. C. and Hatfield, J. S. (1995) Parasitism at the landscape scale: cowbirds prefer forests. Conserv. Biol. 9: 1415-1424.

Hall, L. S. and Rothstein, S. I. (1999) Cowbird control: the efficacy of long-term control and proposed alternatives to standard control practices. Stud. Avian Biol. 18: 254-259.

Hauber, M. E. and Russo, S. A. (2000) Perch proximity correlates with higher rates of cowbird parasitism of ground nesting song sparrows. Wilson Bull. 112: 150-153.

Hayden, T. J., Tazik, D. J., Melton, R. H. and Cornelius, J. D. (2000) Cowbird control program at Fort Hood, Texas: lessons for mitigation of cowbird parasitism on a landscape scale. Pp. 357-370 in J. N. M. Smith, T. L. Cook, S. I. Rothstein, S. K. Robinson and S. G. Sealy, eds. Ecology and management of cowbirds and their hosts. Austin: University of Texas Press.

Hosmer, D. W. and Lemeshow, S. (2000) Applied logistic regression. New York: John Wiley. Johnsgard, P. A. (1997) The avian brood parasites. New York: Oxford University Press.

Kluza, D. A. (1998) First record of Shiny Cowbird (Molothrus bonariensis) in Yucatán, Mexico. Wilson Bull. 110: 429-430.

Krabbe, N. (2004) Pale-headed Brush-Finch Atlapetes pallidiceps (Aves: Emberizidae): notes on population size, habitat, vocalizations, feeding, interference competition, and conservation. Bird Conserv. Int. 14: 77-86.

Kus, B. E. (2002) Fitness consequences of nest desertion in an endangered host, the Least Bell's Vireo. Condor 104: 795-802.

Larison, B., Laymon, S. A., Williams, P. L. and Smith, T. B. (1998) Song Sparrows vs cowbird brood parasites: impacts of forest structure and nest-site selection. Condor 100: 93-101.

Lichtenstein, G. and Sealy, S. G. (1998) Nestling competition, rather than supernormal stimulus, explains the success of parasitic brown-headed cowbird chicks in yellow warbler nests. Proc. R. Soc. Lond. B 265: 249-254. 
Machlis, L., Dodd, P. W. D. and Fentress, J. C. (1985) The pooling fallacy: problems arising when individuals contribute more than one observation to the data set. Z. Tierpsychol. 68: 201-214.

Marin, M. (2000) The Shiny Cowbird (Molothrus bonariensis) in Chile: introduction or dispersion? Its hosts and parasitic trends. Ornitol. Neotrop. 11: 285-296.

Martin, T. E. and Geupel, G. R. (1993) Nest-monitoring plots: methods for locating nests and monitoring success. J. Field Ornithol. 64: 507-519.

Massoni, V. and Reboreda, J. C. (2002) A neglected cost of brood parasitism: egg punctures by Shiny Cowbirds during inspection of potential host nests. Condor 104: 407-412.

McLaren, C. M. and Sealy, S. G. (2000) Are nest predation and brood parasitism correlated in Yellow Warblers? A test of the cowbird predation hypothesis. Auk 117: 1056-1060.

Oppel, S., Schaefer, H. M. and Schmidt, V. (in press-a) Description of the nest, eggs and breeding behavior of the endangered Pale-headed Brush-Finch in Ecuador. Wilson Bull.

Oppel, S., Schaefer, H. M., Schmidt, V. and Schröder, B. (in press-b) Habitat selection by the pale-headed brush-finch (Atlapetes pallidiceps) in southern Ecuador: implications for conservation. Biol. Conserv.

Payne, R. B. (1997) Avian brood parasitism. Pp. 338-369 in D. H. Clayton and J. Moore, eds. Host - parasite evolution: general principles and avian models. New York: Oxford University Press.

Peterjohn, B. G., Sauer, J. R. and Schwarz, S. (2000) Temporal and geographic patterns in population trends of Brown-headed Cowbirds. Pp. 21-34 in J. N. M. Smith, T. L. Cook, S. I. Rothstein, S. K. Robinson and S. G. Sealy, eds. Ecology and management of cowbirds and their hosts. Austin: University of Texas Press.

Petit, L. J. and Petit, D. R. (2000) Brown-headed Cowbird parasitism of migratory birds: effects of forest area and surrounding landscape. Pp. 265-270 in J. N. M. Smith, T. L. Cook, S. I. Rothstein, S. K. Robinson and S. G. Sealy, eds. Ecology and management of cowbirds and their hosts. Austin: University of Texas Press.

Reineking, B. and Schröder, B. (in press) Computer-intensive methods in the analysis of species-habitat relationships. Proceedings "Genes, bits and ecosystems" theory in ecology. Frankfurt: Peter Lang.

Robinson, S. K., Brawn, J. D., Morse, S. F. and Herkert, J. R. (1999) Use of different habitats by breeding Brown-headed Cowbirds in fragmented western landscapes. Stud. Avian Biol. 18: 52-61.

Rothstein, S. I. and Cook, T. L. (2000) Cowbird management, host population limitation, and efforts to save endangered species: introduction. Pp. 323-332 in J. N. M. Smith, T. L. Cook, S. I. Rothstein, S. K. Robinson and S. G. Sealy, eds. Ecology and management of cowbirds and their hosts. Austin: University of Texas Press.

Rothstein, S. I. and Robinson, S. K. (1994) Conservation and coevolutionary implications of brood parasitism by cowbirds. Trends Ecol. Evol. 9: 162-164.

Rothstein, S. I. and Robinson, S. K. (2000) Population trends of cowbirds and hosts and relevant methodology: introduction. Pp. 13-20 in J. N. M. Smith, T. L. Cook, S. I. Rothstein, S. K. Robinson and S. G. Sealy, eds. Ecology and management of cowbirds and their hosts. Austin: University of Texas Press.

Rothstein, S. I., Verner, J., Stevens, E. and Ritter, L. V. (1987) Behavioral differences among sex and age classes of the Brown-headed Cowbird and their relation to the efficacy of a control program. Wilson Bull. 99: 322-337.

Schröder, B. (2002) ROC-AUC calculation. http://www.uni-oldenburg.de/landeco/ Download/Software/Roc/Roc.htm. Accessed 10 January 2003.

Smith, J. N. M. (1999) The basis for cowbird management: host selection, impacts on hosts, and criteria for taking management action. Stud. Avian Biol. 18: 104-108.

Smith, J. N. M. and Rothstein, S. I. (2000) Brown-headed Cowbirds as a model system for studies of behavior, ecology, evolution, and conservation biology. Pp. 1-9 in J. N. M. 
Smith, T. L. Cook, S. I. Rothstein, S. K. Robinson and S. G. Sealy, eds. Ecology and management of cowbirds and their hosts. Austin: University of Texas Press.

Sokal, R. R. and Rohlf, F. J. (1995) Biometry. New York: W. H. Freeman.

Staab, C. A. and Morrison, M. L. (1999) Managing riparian vegetation to control cowbirds. Stud. Avian Biol. 18: 18-22.

Strausberger, B. M. (2001) The relationship of habitat and spatial distribution of nests with Brown-headed Cowbird parasitism of Red-winged Blackbirds. Wilson Bull. 113: 129-261.

Taylor, D. M. (1986) Effects of cattle grazing on passerine birds nesting in riparian habitat. J. Range Manage. 39: 254-258.

Tewksbury, J. J., Martin, T. E., Hejl, S. J., Redman, T. S. and Wheeler, F. J. (1999) Cowbirds in a western valley: effects of landscape structure, vegetation, and host density. Stud. Avian Biol. 18: 23-33.

Uyehara, J. C. and Whitfield, M. J. (2000) Association of cowbird parasitism and vegetative cover in territories of southwestern Willow Flycatchers. Pp. 204-209 in J. N. M. Smith, T. L. Cook, S. I. Rothstein, S. K. Robinson and S. G. Sealy, eds. Ecology and management of cowbirds and their hosts. Austin: University of Texas Press.

Verbyla, D. L. and Litvaitis, J. A. (1989) Resampling methods for evaluating classification accuracy of wildlife habitat models. Environ. Manage. 13: 783-787.

Ward, D. and Smith, J. N. M. (2000) Interhabitat differences in parasitism frequencies by Brown-headed Cowbirds in the Okanagan Valley, British Columbia. Pp. 210-219 in J. N. M. Smith, T. L. Cook, S. I. Rothstein, S. K. Robinson and S. G. Sealy, eds. Ecology and management of cowbirds and their hosts. Austin: University of Texas Press.

Whitfield, M. J. (2000) Results of a Brown-headed Cowbird control program for the southwestern Willow Flycatcher. Pp. 371-377 in J. N. M. Smith, T. L. Cook, S. I. Rothstein, S. K. Robinson and S. G. Sealy, eds. Ecology and management of cowbirds and their hosts. Austin: University of Texas Press.

Whitfield, M. J., Enos, K. M. and Rowe, S. P. (1999) Is Brown-headed Cowbird trapping effective for managing populations of the endangered Southwestern Willow Flycatcher? Stud. Avian Biol. 18: 260-266.

Winter, K. J. and McKelvey, S. D. (1999) Cowbird trapping in remote areas: alternative control measures may be more effective. Stud. Avian Biol. 18: 282-289.

Wood, D. R. and Bollinger, E. K. (1997) Egg removal by Brown-headed Cowbirds: a field test of the host incubation efficiency hypothesis. Condor 99: 851-857.

Young, J. S. and Hutto, R. L. (1999) Habitat and landscape factors affecting cowbird distribution in the northern Rockies. Stud. Avian Biol. 18: 41-51.

STEFFEN OPPEL and BORIS SCHRÖDER

Landscape Ecology Group, Carl-von-Ossietzky University Oldenburg, P. O. Box 2503, 26111 Oldenburg, Germany. E-mail: steffen.oppel@gmx.net

H. MARTIN SCHAEFER and VERONIKA SCHMIDT

Institute of Avian Research, "Vogelwarte Helgoland", An der Vogelwarte 21, 26386 Wilhelmshaven, Germany

Received 21 February 2003; revision accepted 6 January 2004 